\title{
El lugar de la memoria: Where Memory Lies
}

\author{
Liliana E. Correa, University of Western Sydney
}

The Victim Speaks:

Labelled as 'the femme from the South of this Border'

The Woman Latin other

The Mother Single Lover

The lover: plural and fluid

Sometimes more the mother than the woman

Sometimes more the lover than the mother

Never-the-Less nor the-More

Always Mother Always Woman Always Other

Then with that 'sudden contraction' in a split of soul and a second of pain: she, the whole of who she has to become, arises from memory, place and responsibilities. From a minuscule and obscure sphere of silence, and salivating over her own body, she awakes to one word while the South of her heart, in an incommensurable and transcultural sound, calls to her: toc toc toc ... with the wisdom of generations and latitudes breaks the silence and speaks in tongues.

Image 1. Viajes: Taking my mother's ashes to Mar de Cobo, Buenos Aires, August 2008, photographed by L. Correa. 


\section{Then where does the story begin?}

The longing for the most familiar takes me back every time to a repetition, a reenactment of some sort. I rehearsed over and over those daily rituals with my own children trying to reconstruct my version of what was part of my childhood's memories, extending myself through what I know best in this, our new context. Memory, belonging and continuity based on history and those unthinkable events, somehow unnamed that stay somewhere: they will get re-told, over and over again, letting the storyteller continue to unravel and recuperate moments.

Memory gives us context and place, a geographic and historical location with references to the past. At the same time memory places us in an active present, making my actions relevant to this here and now in a space of absolute belonging. Perhaps this is why we, migrants repeating our millennial customs with a sense of attachment, continue to transform the ordinary into the extraordinary so a story then must be told. Within this space are conflicting desires and responsibilities, and constant negotiations take place; here is where memory plays an essential role mediating between geographic and imaginary homes.

For Bennet 'sense memory is about tapping a certain kind of process; a processes experienced not as a remembering of the past but as a continuous negotiation of the present with indeterminable links with the past. The poetics of sense memory involve no so much speaking of but speaking out of a particular memory or experience - in other words speaking from the body sustaining sensation' (2008: 38). Through my own process of 'speaking out' selected memories, I rebuild as an affective construction a space that contains me; only then this 'space' can be named and pronounced in English and Spanish alike: 'home/hogar.'

I purposely construct a mise-en-scene: objects, books, toys, newspapers, photographs or paintings, kitchen utensils, materials and clothes laden with traces of our stories, constant references to what is to come for my children and I, our memory of our culture. Nevertheless, while these reconstructions are dynamic, memory is not static. Eventually my children will add or delete bits and pieces as they create their ownership of their cultural context. In the meantime our present space resembles the most familiar of past places, making us feel contained and secure, in particular when what waits on the other side of the door is, at times, incomprehensible. 
In A Lover's Discourse, Barthes writes:

Language is a skin: I rub my language against the other. It is as if I had words instead of fingers, or fingers at the tip of my words. My language trembles with desire. The emotion derives from a double contact: on the one hand, a whole activity of discourse discreetly, indirectly focuses upon a single signified, which is "I desire you" ... on the other hand, I enwrap the other in my words, I caress, brush against, talk up this contact, I extend myself to make the commentary to which I submit the relation endure. (1990: 73)

Reflecting on Barthes's fragments that form his structural discursive portrait brings me to a justification, and to my own linguistic repertoire: the language I own and its intrusion into the domineering English-academic language. My language as a site of loved metaphoric games: 'Language is a skin' and a skin is what you see, seeing is what I speak: of - from — at. I then speak my skin. Because my language is 'I,' English cannot be allowed to overwrite me. My language makes me visible, and every time I trip over mispronounced words and wrong spellings, my subalternity is reiterated. Nevertheless to be heard, seen and understood I must attain the voice of another. My proposition, then, is to explore an inter-language in an attempt to reconcile both languages: English and Spanish and a creative academic practice. But Barthes continues: "I cannot write myself ... what, after all, is this "I" who would write himself? ... All I might produce, at best, is a writing of the Image-repertoire; and for that I would have to renounce the Image-repertoire of writing - would have to let myself be subjugated by my language' (1990: 99).

In a self-reflective manner I want to show the role memory plays as psychological and emotional sustenance. And through examples from Latin American Australian artists' testimonials, I want to demonstrate how memory also permeates the migrant/exile artists' work. ${ }^{1}$ In Emphatic Vision Bennett (2008: 11) argues that the 'affective quality of art' contributes to understanding trauma and loss. In my experience, art has the capacity to change perceptions by triggering reflection and understanding about others. Artistic practices help to alleviate a sense of fracture and isolation by reasserting their maker's identity, and by facilitating a transition between cultures as well.

I felt seduced by the storyteller role and a strong desire to document the stories of artists I have encountered since my arrival in Sydney in 1984. Toni Morrison's analysis of her role as a writer, and in relation to the slave narratives, autobiographies and memoirs,

\footnotetext{
${ }^{1}$ The term artist refers to those people who have managed to sustain art practices, whether or not these provide them with a source of income or fulltime employment in this sector.
} 
clearly showed me that what gives us access to artists' lives is found in the intersection between histories, memories and imagination. She states:

The exercise is also critical for any person who is black, or who belongs to any marginalized category, for historically, we were seldom invited to participate in their discourse even when we were its topic. Moving that veil aside requires therefore certain things. First of all I must trust my own recollection. I must also depend on the recollection of others. Thus memory weights heavily in what I write in how I begin and what I found to be significant ... these "memories within" are the subsoil of my work. But memories and recollections won't give me total access to the unwritten interior life of these people. Only the act of the imagination can help me. (1990: 302)

The artist's work is the material representation where the factors that make the work unique and express the artist's identity and visibility can be found. Writing in both languages creatively is one form of reflecting on and analyzing our experiences.

\section{Where memory lies}

Memory dwells in objects, informs our attitudes and stimulates our senses. Aided by material and symbolic memory, migrants reconstruct and recreate an idea of 'home.' At the same time, this cultural memory, when perceived by others, may generate certain expectations about the kind of artwork or performance that artists from a Latin American background are supposed to produce. ${ }^{2}$ For example, some artists were prey to a private entrepreneurialism that took over the spaces and activities born out of culturally specific needs, not necessarily commercial ones. This commercialization or privatizing turned potential spaces for transformative interventions into exercises in the management of difference, one which sustained borders of 'otherness.' To challenge these notions and demarcations, cultural productions must be articulated in such a way as to be relevant to contemporary Australian audiences. As Bal notes, reflecting on borders, identity and exile:

Borders are not lines but spaces- territories that are contested and fought over, but shared spaces nonetheless .... Some forms of occupation (colonialism, for instance) can generate a mode of resistance that may enhance survival. In a more cultural dynamic, the negotiation of borders can also be a model for interpretation .... Practices of occupation, resistance, and interpretation-are all forms of negotiation. (2008: 10)

In Bal's understanding, borders should not be seen as dividing lines but as places of negotiation and exchange. In my view artistic expressions are a mode of negotiation. $\mathrm{Bal}$ also refers to the fact that experiences such as exile assault the relationship between place and person, and produce strong emotions, such as nostalgia (2008: 26). Our

\footnotetext{
${ }^{2}$ I am using the term Latin American to refer to people coming from Mexico, the Caribbean, Central and South America and who reside in Australia.
} 
memories feed this emotion, in many cases giving impetus to imaginative and creative work. Cohabiting that borderised place are grief and the irrecoverable loss of place, dislocation, frustration and pain. But it is not enough to inhabit this space: it also requires a capacity for a constant transformation and self reinvention, like that represented in the work of migrant-exile artists.

Homi Bhabha, reflecting on the Mexican American Guillermo Gómez Peña's performance work, states:

The borderline work of culture demands an encounter with 'newness' that is not part of the continuum of past and present. It creates a sense of the new as an insurgent act of cultural translation. Such art does not merely recall the past as social cause or aesthetic precedent; it renews the past, refiguring it as a contingent 'in-between' space, that innovates and interrupts the performance of the present. The 'past-present' becomes part of the necessity, not the nostalgia of living. (1994: 7)

Some Latin American artists in Australia have moved between disciplines and commercial and artistic contexts, enabling them to continue their artistic explorations and, in turn, renewing themselves and their artwork. Many immigrant/exiled artists approach their work in a multidisciplinary manner, since becoming fluent in new artistic expressions and learning to negotiate across sectors is a necessary survival skill. Multidisciplinary practice and cross-cultural engagement have offered opportunities for many Latin American artists to develop their skills and aesthetic approaches in Australia.

\section{Lino Alvarez Carrasco: La Paloma}

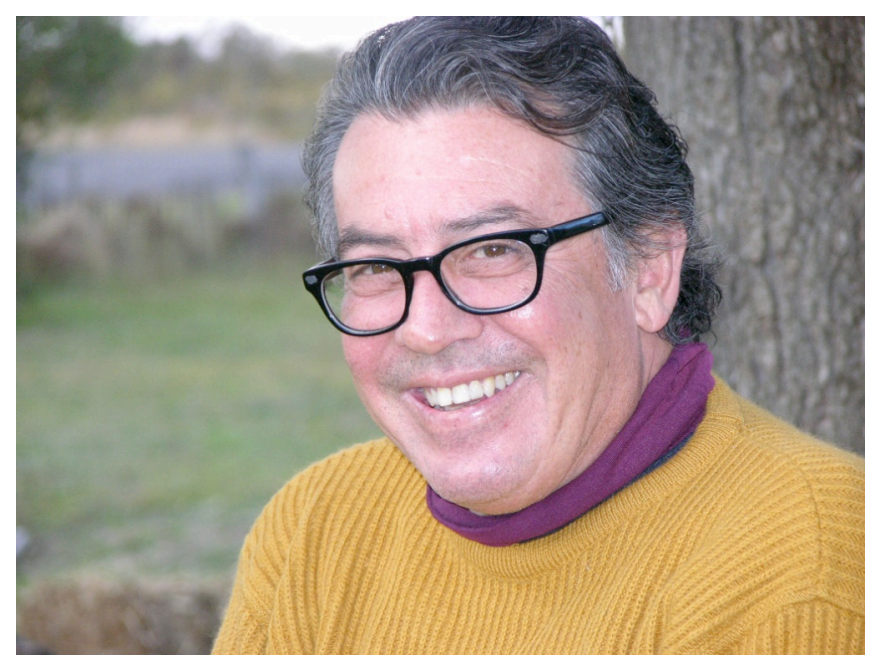

Image 2. Lino Alvarez Carrasco. En el banco: La Paloma, photographed by L. Correa, 2009.

Mexican potter Lino Alvarez Carrasco is an example of an artist who moves between 
commercial and artistic fields successfully. In April 2009 the filmmaker Walter Rojas and I visited Lino at La Paloma Pottery in Hill End, NSW, for the purpose of documenting his story and work. During our conversation Lino recounted one of his recent experiences, a collaboration with the painter Garry Shead. Between 2000 and 2006 Shead produced a series of etchings inspired by the poems of Ern Malley, a madeup literary character from the 1940s. These formed the bases of Shead's paintings on urns made and designed by Lino. This collaboration is an example of a successful and creative partnership between a potter who utilizes traditional techniques learnt in his home country, Mexico, and one of Australia's most acclaimed lyrical figurative painters.

When recounting this experience Lino talks about how, after completing a number of urns for Garry to paint on, they both agreed that the urns as designed were not working adequately to translate the emotions depicted in the paintings inspired by Malley's poems. After playing around with different options, for example, severing the tops or cracking and sculpting parts of them, they came to the conclusion that the work had to be done all over again; so in ritualistic mode all the urns were destroyed and buried, and they started the next morning afresh. Lino agrees that the creative process mediates the intensity of artistic collaboration. In the same way artistic processes are the artists' language, creative articulations that mediate between the artists and mainstream culture. These collaborations are productive because what might for some people be a cultural border that prevents dialogue, is for others a meeting space where creative encounters produce previously unforeseen work.

In the introduction to The Location of Culture, Bhabha urges a move away from:

narratives of originary and initial subjectivities and to focus on those moments and processes that are produced in the articulation of cultural differences. These 'in between' spaces provide the terrain for elaborating strategies of selfhood - singular or communal - that initiate new signs of identity, and innovative sites of collaboration, and contestation, in the act of defining the idea of society itself. (1994: 2)

Listening to Lino's stories gave me insights into how negotiations take place in 'in between spaces'; at the same time they are material proof of how artistic practices can make powerful interventions that challenge cultural representations. Colonial discourse may attempt to place Lino and his work within reach of 'dependency on the concept of "fixity" in the ideological construction of otherness' (Bhabha 1994: 66). As Bhabha explains, racial classification through stereotyping is a necessary component of 
colonialist discourse, for 'the construction of the colonial subject in discourse and the exercise of colonial power through discourse, demands an articulation of forms of difference-racial and sexual' (1994: 67). When Lino arrived in Australia in 1982, his intention was to live off his work as a potter and contribute to his new culture by facilitating an appreciation of ceramics as an art form - in his own words, 'subir el nivel de la cerámica como forma de expresión artística' (to elevate ceramics as another form of artistic expression) (phone conversation 6 April 2009). While filming his testimonial Lino recalled his experience as a new arrival and his first job as a potter:

\begin{abstract}
I was determined to live off my job as a potter, so each morning I would look through the job vacancies section of the Sydney Morning Herald, they were saying to me you must be crazy- a potter! You wouldn't get a job as a potter here. There are no potters in this country, you know? This went on for 8 or 10 days and one day I say to [my father in law] you won't believe it but look at what this says: "potter required" and he couldn't believe it either! ... I went there ... I asked where is the kiln? That is not the job she said, the job is you are going to be seated here in front of the window with a lump of clay and you are going to make pots, but make the pots really slowly. I suddenly realised oh no! I am going to be on show here to attract people into the gallery. At the end of the day I had made all these pots and asked her are we ever going to burn them, oh no, no, destroy them and pack them tightly into the bag and tomorrow when you came back wedge the clay and start all over. I stayed for 3 weeks then I quit and we moved to Balmain. (Original spoken in English, Hill End, April 2009)
\end{abstract}

Artists, in particular those perceived as 'belonging to another culture,' must manage a fluid existence in order to sustain their practice in commercial and mainstream artistic spaces. This fluidity creates dissonance and tensions that challenge or question one's sense of identity. For the artist whose identity is strongly linked to the place of origin, memory is an anchor and a source of inspiration, intrinsically connected to selfrepresentation.

Susan Engels's work on memory and context clarifies my understanding of the strong presence of memories I see at the core of new work by Australian Latin American artists. Engels explains why in memory and recollections one must always be the protagonist portraying a positive image, helping in this way to defuse conflict: 'We use the process of memory to reduce dissonance. If we are always working to maintain a positive and consistent self concept, then one of the main ways we can do this is through the stories we tell about what happened ... Recollections of the immediate and distant past allow us to reduce dissonance and maintain a positive self-concept' (1999: 45). In hindsight I recognise that continual questioning helps this process. Expressed in day-to-day interactions, questions that are asked of us circle around the language of origin, the year of arrival, and the reasons for living from our artistic practices versus 
merely practising a 'hobby.' Once territory is marked by borders, different questions arise that tend to be more inclusive, indicating superficial interest and appreciation of our expertise about everything to do with our countries of origin, from cooking to sports and politics (see Coronado 2003: 117). The host country's questioning of our cultural origins not only creates dissonance but sustains a sense of otherness, constructing us as ethnicised subjects, emsuring that our professional choices, identities and ethnicities become the focus of debate, rather than the work and histories affecting our personal and professional life.

For Arias, we are performed into being ethnicised subjects:

By means of performance and in this reiterative re-enactment of our culture, within a space dominated by other more powerful groups, [we] sustain a collective identity ... Ethnicity is constructed performatively and functions metonymically. Ethnic performativity is a function of the reiterative practice of regulatory discursive regimes that control the formation of personal and collective identity' (2001: 81)

Reenactments and interpretations of my own 'Latinamericanist' self have similarly required a participatory audience. To call oneself Latin American in Australia implied in the 1970s and 1980s that one was an expert about some cultural form or another. If one did not play guitar surely one could dance tango. A different dish must be cooked each week in order to merit the title: 'expert.' But if unable to deliver the dish or the entertainment, we Latin Americans became prolific lovers and, in true revolutionary spirit, embraced the Sydney Latin Myth, roaming the streets of the city into the early hours.

Alongside the ongoing reconstruction of ethnicity in and outside our personal-familial spaces, memory plays a crucial role in the reconstruction and sustenance of identity. As Willis asserts:

Cultural identity is certainly about the maintenance of the self as a separate and viable force, irreducible to institutional role, ideological definition or dominant social representation. But the meaning making involved is not free and open but intrinsically framed and constrained, as well as enabled, in specific and contingent ways, by powerful external structural determinations. (2000: 4)

Memory is dynamic; it carries and plays distinctive social and cultural functions and makes past histories relevant and contemporary, while offering another dimension of understanding to the act of ethnic performativity, particularly in relation to art practices. The relationship between memory, cultural self or identity, and ethnicity is complex, 
and further modulated by displacement from one's culture. Whether one is a migrant, traveller or exile by choice or force, many possible 'structural determinations' are at work in these relationships. Observing and challenging those determinations is one way of understanding the importance of self-representation for Latin American artists in Sydney.

Gabriela Coronado, reflecting on the emotional sustenance required by migrants, argues that memories play an undeniable role in sustaining a sense of self:

La importancia de los recuerdos es innegable, y en el contexto migratorio adquieren además un valor central como sustento emocional, para uno mismo y para el reforzamiento, o no, de los vínculos con nuestros espacios sociales y afectivos. Representan un anclaje con nuestro pasado y nos conectan con aquellos que se quedaron.

The importance of memories is undeniable, and within the context of migration they acquire a central value as emotional sustenance, to oneself and as reinforcements, or not, of social and emotional bonds. They represent an anchor to our past and connect us with those who stayed behind. $^{3}$ (2009: 1)

Context and interactions in the new environment play an enormous role in remaking artists' life stories and work. Memories also connect us in different ways and at different levels of experience. When the first Latin Americans arrived in Sydney during the early 1970s, they brought with them all the elements of a Greek Tragedy, including the Chorus. That first wave of Latin American migrants left behind countries either at war or under dictatorship. They brought with them cultural traits, culinary customs, traditions, musical instruments and artefacts. Above all they arrived with lived memories and stories, real and fictional. Sydney was ready to see the spectacle, take part in it, pay for it and embrace it from every angle. Newly arrived Latinos realised that to proclaim themselves Latin American exiles and artists was not disadvantageous, and they were not considered 'less professional' or mere amateurs. In the new environment artistic expression was indispensable for facilitating the transition between cultures.

Willis states that everyday creativities and their sensory affects, which penetrate us, can be imagined as a culture 'thinking' for its members; these penetrations guarantee the longevity of the cultural form: 'They are not simply autonomously meaningful in an enclosed and cultural world, but meaningful with respect to context' (Willis 2000: 35). Artistic expressions work as sensory penetrations and at their heart are the memories mapping our histories. Visual, sound, performance and other modes of art-making

\footnotetext{
${ }^{3}$ Translations in this essay are mine unless otherwise noted.
} 
mobilize affect, reasserting or validating our memories and identities. As I enter spaces where artists from the Latin American community perform, memory stimulates my senses; even when I feel nostalgic or melancholic I am at ease, at home. The arousal of past memories and experiences softens the tensions emanating from our daily performance of multiple roles. This sensation, a sensual rather than cognitive one, is as personal as it is collective, without necessarily confirming the existence of a common migrant-artist imaginary. Artistic expression reiterates and reasserts a sense of belonging that is normally absent in daily life: proactive cultural interventions occur in the specific spaces that enable a culture to think. There memories lie.

In Sydney and the surrounding region a number of such spaces exist. Located within the Addison Road Community Centre in Marrickville is La Casa Latinoamericana (Latin American Hut), which functions as a cultural and social gathering space. Café Carnivale is run from different venues in the inner city, and in the west and north of Sydney. This world music event is an initiative of its musical director Justo Díaz. He acknowledges that Café Carnivale is a continuation of La Peña, the Latin American Cultural Centre based in Sydney from 1980 to 1994. Another example is Studio 40, established by the painter Carlos Barrios and his wife, in Robertson, NSW.

\section{Carlos Barrios: Studio 40}

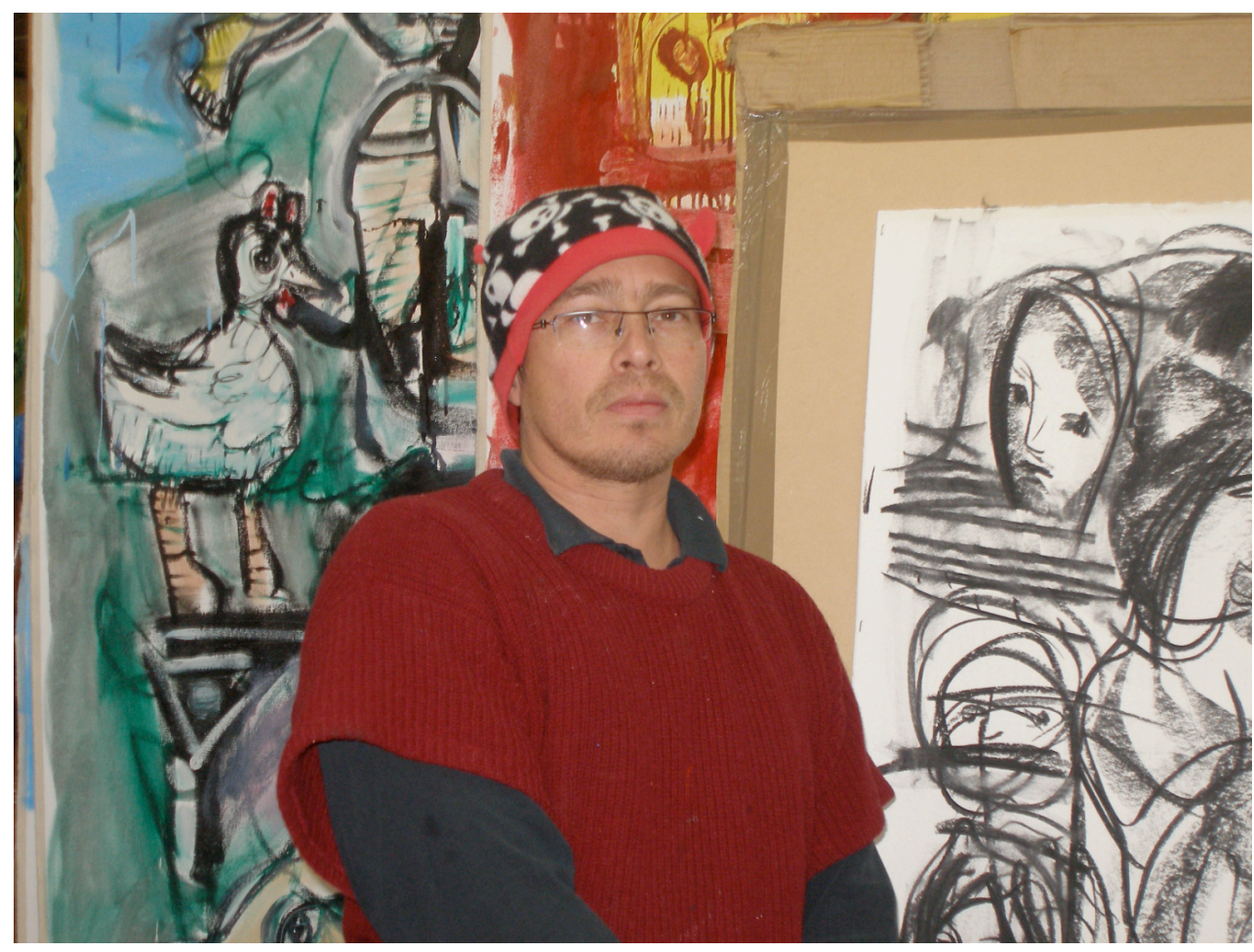

Image 3. Carlos Barrios, Studio 40, photographed by L. Correa, 2009. 
Empecé como autodidacta en El Salvador. En 1990 vine a vivir a Australia y entré a la Escuela Nacional de Arte, estuve un año y medio. Sentí que querían influenciarme, yo ya tenía algunas ideas formadas, tal vez por el mismo hecho de haber crecido en la guerra civil, hay ciertas cosas que sentía necesario expresarlas que la escuela las miraba, creo como muy superficiales y para mi eran importantes y luego yo miraba lo que ellos querían hacer y era un poquito aburrido. Entonces formamos un estudio con Darío Palermo, Juan Rosales, Carlos Fimenias y otros artistas. Le pusimos Consortium of the Artists Student Association ( CASA) era nuestra casa, en Rozelle, Sydney. Cuatro de Latinoamérica: Darío Palermo, Carlos Fimenias, Juan Rozales y yo. Hoy esta cooperativa tiene dos fábricas con más de 60 artistas, la mayoría Australianos. (Carlos Barrios, Robertson, NSW, 2009)

I am a self-taught artist. I came to Australia in 1990 and entered the National Art School where I stayed for one and a half years. I felt that they wanted to influence me. I came with some preconceived ideas perhaps because I grew up during the Salvadorian Civil War. There were certain things that I felt necessary to express that the School thought were superficial, but they were important to me. Then I looked at what they wanted me to do and I thought they were a little boring. So with Dario Palermo and nine other artists we formed The Consortium of the Artists Students Association (CASA). This was for us our home, in Rozelle Sydney, four of us from Latin America: Dario Palermo, Carlos Fimenias, Juan Rosales and myself. This cooperative of artists today hosts 60 artists in two studios, most Australians.

In El Salvador Carlos attended a Jesuit school where the emphasis was on science rather than arts, but the curriculum also had a strong social agenda. At the age of 18 he decided to become a painter: 'Antes de aprender a leer y escribir ya había elegido mis libretas de dibujo' (Before I could read or write I had chosen my sketching books).

Carlos began taking private lessons with the renowned Salvadorian painter, Ramón Merino, who lived in a nearby neighbourhood. In 1990 he migrated to Australia. Fascinated by trains he would travel from Auburn into the city and, through observation and drawing, started to understand the ways of the city. In response to my question about whether memory is kept alive through his work, Carlos said:

Yo llevo una memoria genética donde hay memorias y memorias, europeas, indígenas de Latinoamérica-Mesoamérica y todas esas cosas me dan elementos nuevos, tengo la memoria de mis padres, de mis ancestros, entonces muchas veces los siento a ellos también, no sé si es una ilusión o una realidad .... Andamos llevando nuestros espíritus y cuando estoy trabajando pienso muchas veces en el pasado y todo eso se queda plasmado. Puedes estar trabajando 5 horas en el estudio y en esas 5 horas que estás trabajando hay memorias, hay deseos, luego hay cosas del presente y todo se va mezclando allí están todos esos elementos y el trabajo va a mostrar todos esos elementos. (Carlos Barrios, Robertson, NSW, 2009)

I carry a genetic memory where there are memories and memories, Europeans, Latin AmericanMesoamerican indigenous peoples' memories, and all those things give me new elements. I hold my parents, my ancestors' memories then many times I feel them too, I don't know if it is an illusion or reality .... We carry our spirits and when I am working I think very often about the past and all those elements are portrayed. One can be working 5 hours in the studio and in those 5 hours of work there are memories, desires and other things about the present moment, and it all gets mixed up and your work is going to show all those elements. 


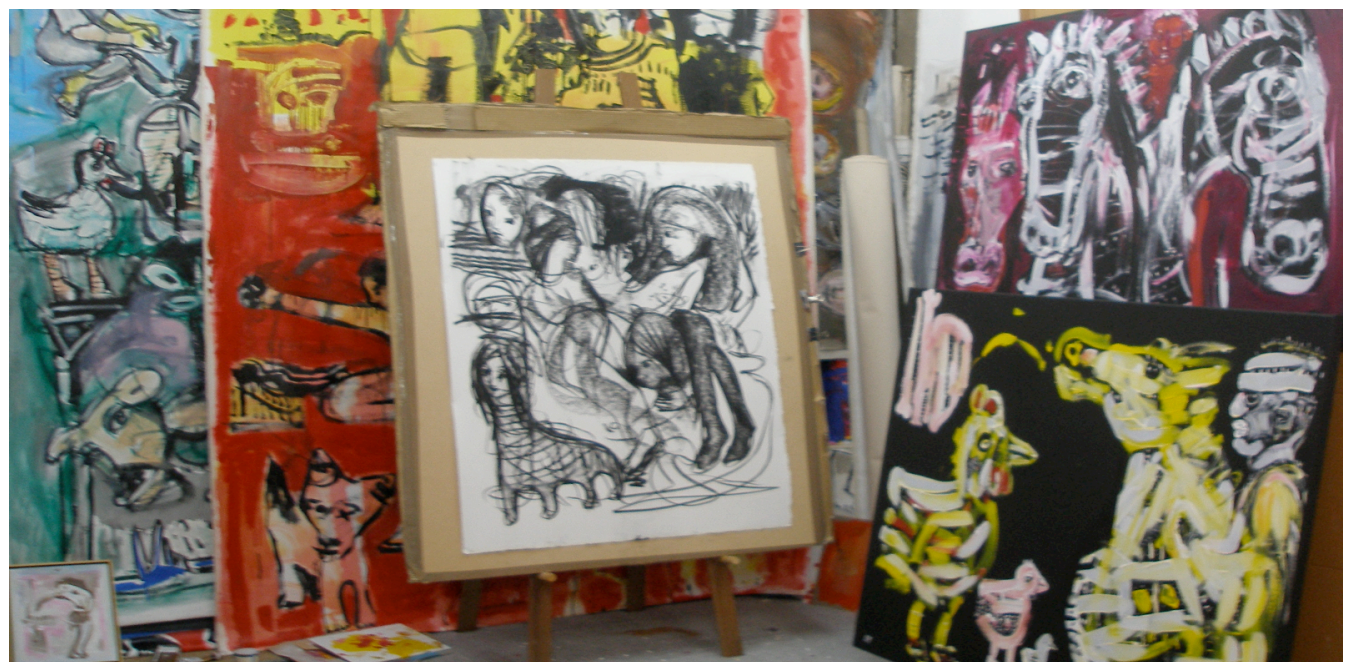

Image 4. El trabajo de Carlos, photographed by L. Correa, 2009.

This image shows examples of Carlos's work. Entering his studio space in 2009 I felt strongly connected to these and other pieces, in particular his drawings, the black and white free style figurative work as strong as other pieces where bold colours took me back to the depth, strength, and yet subtlety of the colours of the land and landscapes of my country and others I had visited. Creative work allows us to process emotions in creative modes that, in turn, reassert cultural visibility.

\section{My recollections}

Todo está escondido en la memoria refugio de la vida y de la historia (Everything is hidden in memory, refuge of life and history). Song by León Gieco.

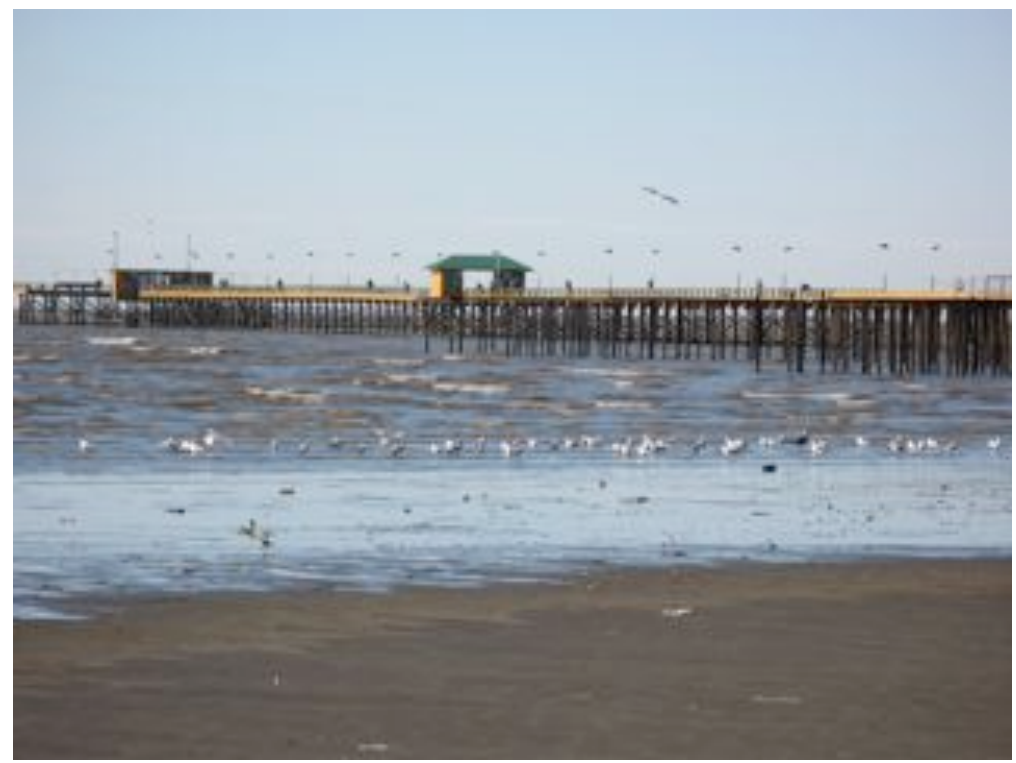

Image 5. El Rio: Quilmes, Buenos Aires, photographed by L. Correa, 2007. 
By 1981 in Argentina I had joined the early morning queues of my city's unemployed, attended Teachers College in La Plata, and actively engaged with one of the Socialist parties of Buenos Aires. This was not uncommon practice for a young student, since at the time most Latin American countries were ruled by bloody dictatorial regimes and corrupt governments. In Buenos Aires one was either on the right or the left of politics: being neutral, apolitical or apathetic was rarely an option. After the Malvinas war I agreed to follow some family members who had migrated to Australia. It is not difficult for me to remember those years - full of idealistic activism, love, camaraderie, creativity and political debate, I was perhaps one of the few who, by chance or luck, was untouched by the military, the police or the extreme right that abused, tortured, killed, and made many members of my generation disappear. I carried with me to Australia a highly idealised memory of political-cultural practices, emotional sustenance for reinforcing my identity. As I entered this new culture I sought out spaces in which I could still be an activist in some way or another, and situated myself within a community of expatriates and cultural activists who spoke the same tongue. From 1984 until the late 1990s our common language, rather than English, was predicated on our memory of who we were and how we were to continue our cultural politics outside our countries of origin.

As a newly arrived migrant coming into a contrasting culture with a language different to my own and very different social dynamics, I noticed that the Latin American families I interacted with during my first years in Sydney would repeat the same daily practices as those performed in their countries. During the first year after my arrival I moved between three different households. An ethnographic account of one family would have shown the following. This family consisted of a father, mother and two daughters who attended high school and worked casual jobs. Every morning the family would leave the house after breakfast to attend to their respective activities, the father to the factory, the mother to a cleaning job, the children to school. In some cases factories provided English language courses and there were also other 'English as a second language' courses that migrants attended after working hours. In most cases, however, those working in factories would have learnt Italian first instead of English. Back in the family home Spanish language reigned through the SBS radio, TV programs and local Spanish press. Family conversations covered topics ranging from Latin American politics and show business, family news, and updates from home about neighbourhood 
births, deaths, marriages and disgraces. The domestic space was marked by common rituals: unlike the Australian evening meal time of $6.30-7.30 \mathrm{pm}$, for the usual Latin American family dinner was not served before $9.00 \mathrm{pm}$. For emergencies and communication in English children became the family's interpreters. Families who came earlier, or around the same time as I did, have expressed to me the sentiment of living in two different 'worlds,' with English beyond the front door and Spanish behind it. Another common practice was to leave the house after dinner and roam the streets in search of spaces to socialize and meet friends. Somewhere in the Northern beaches, for example, Lino Alvarez would walk the streets after dinner in search of the coffee shop, as the musician Justo Díaz did in the 1970s up and down King Street, looking for a space to play with other musicians, or as the painter Abigail Lutzen did in the early 1990s around the streets of Liverpool, in the southwest of Sydney, also seeking a bar or coffee shop. And when the coffee shop, the bar or a book in Spanish was found it was as if a lost family member had arrived unexpectedly, a moment for celebration. A play written, a poem recited or song sung, all became our shared experience of memory in the making a geography traced by all the stories, in which the real, quasi-real and unreal dared to be pronounced in our accents. Most of us encountered a very empty and silent nocturnal city; places of social interaction were scarce and not easy to find for the newly arrived. One image of the city I hold during the early 1980s was an endless set of empty night-time escalators and quiet streets dressed in fluorescent lights. Nevertheless this is not to say there were no bars, clubs and bands where young and not so young Latin Americans would gather for social and cultural interactions of any kind. Most would remember The Taxi Club or The Journalist Club and a few other Jazz venues open until early morning, and coffee shops such as The Piccolo and Badde Manors.

In 1984 my day began with a trip from Petersham to Warringa Mall at 4 am where I earned my weekly allowance as a cleaner. I would finish in time to get to my 'Onarrival' English class at Caltex House in Circular Quay and, at the end of the day, I packed my bag with a bunch of new words, and headed for the Spanish Café on Liverpool Street. Here an irritable Spaniard with dirty finger nails provided me with the most exquisite chocolate con churros and, depending on his mood, I could end up being kicked out or offered a glass of free red wine to extend the conversation until closing time. Here I had my first encounters with other Latinos who made me understand the possibility of remaking oneself. There was no chance that facts discussed were going to 
be corroborated by anyone, no reason to doubt any story told and, so far away from home in the new land of possibilities, al mejor postor un impostor! To the highest bidder comes the best impersonator.

We had them all, the Victor Jaras and Ché Guevaras, true protagonists of revolutionary causes; with our capacity for reinvention, and thanks to so much poetic license and magic realism, we played, dressed and acted such roles. There were times when one had no need to finish a sentence; our interlocutors would conclude it in the most tragic and romantic manner. Romanticizing our 'Latinidad' was not purely up to us; but it was a construction suited to the times and place. Latin America was not totally unknown by Australians, though particularities of language, idiosyncrasies and distinctive cultural expressions and practices were not taken into much consideration in the Australian construction of us 'Latins.' During the 1970s Australians associated with the Trade Union movement, and the Communist and Socialist parties, played important roles in supporting transitions to democracies in Latin America, and many Australian artists and activists supported these causes. There were many stories, most tragic rather than magical.

Movimientos como los movimientos de una pieza musical tal vez una Sonata para una orquesta de cámara. Invitando músicos callejeros y artistas de ocasión, cantadas o bailadas, nocturnas serenatas. Piezas individuales como pequeños monólogos entrelazados por los hilos conductores de alguna historia. Las orquestas de cámara no tocan en grandiosas salas sino en pequeñas salas de grandiosos teatros. Una sofisticada conversación como lo vislumbro Hyden. Apertura, movimientos, comienzos, insinuaciones y finales descodifican lo que fuimos y lo que hoy somos. Fluidez, aquello que nunca está estático sinó en un continuum y como algún mar de Agosto Atlántico o Pacífico nos recupere en cada ida y vuelta. Apertura y movimiento hacia todo lo posible o lo deseado y de un solo golpe dejarse llevar hacia las palabras que la espuma dibuja y el agua desdibuja.

Image 6, Viajes interiores, Bundanoon, photographed by L. Correa, 2009. 
Movements like those written for a chamber orchestra's sonata, inviting street musicians and occasional artists, danced or sung nocturnal serenades. Individual pieces like intertwined monologues hung by threads of stories from somewhere. Chamber orchestras don't play in grandiose salons but rather in small salons of grandiose theatres. A sophisticated conversation as Hyden might have foreseen. Opening, movements, beginnings, insinuations and finales decode who we were and who we have become. Fluidity, that which is never static rather in a continuum, like Atlantic or Pacific oceans in August, recuperate us in departures and returns. Opening and movement towards what is all possible and desired and with one blow let oneself be carried towards those foam drawn words that the waves will then make fade away. Histories, retold, transformed by present interactions and collaborations rendering place to new forms as in poetry.

\section{Mario Licón Cabrera: El Poeta}

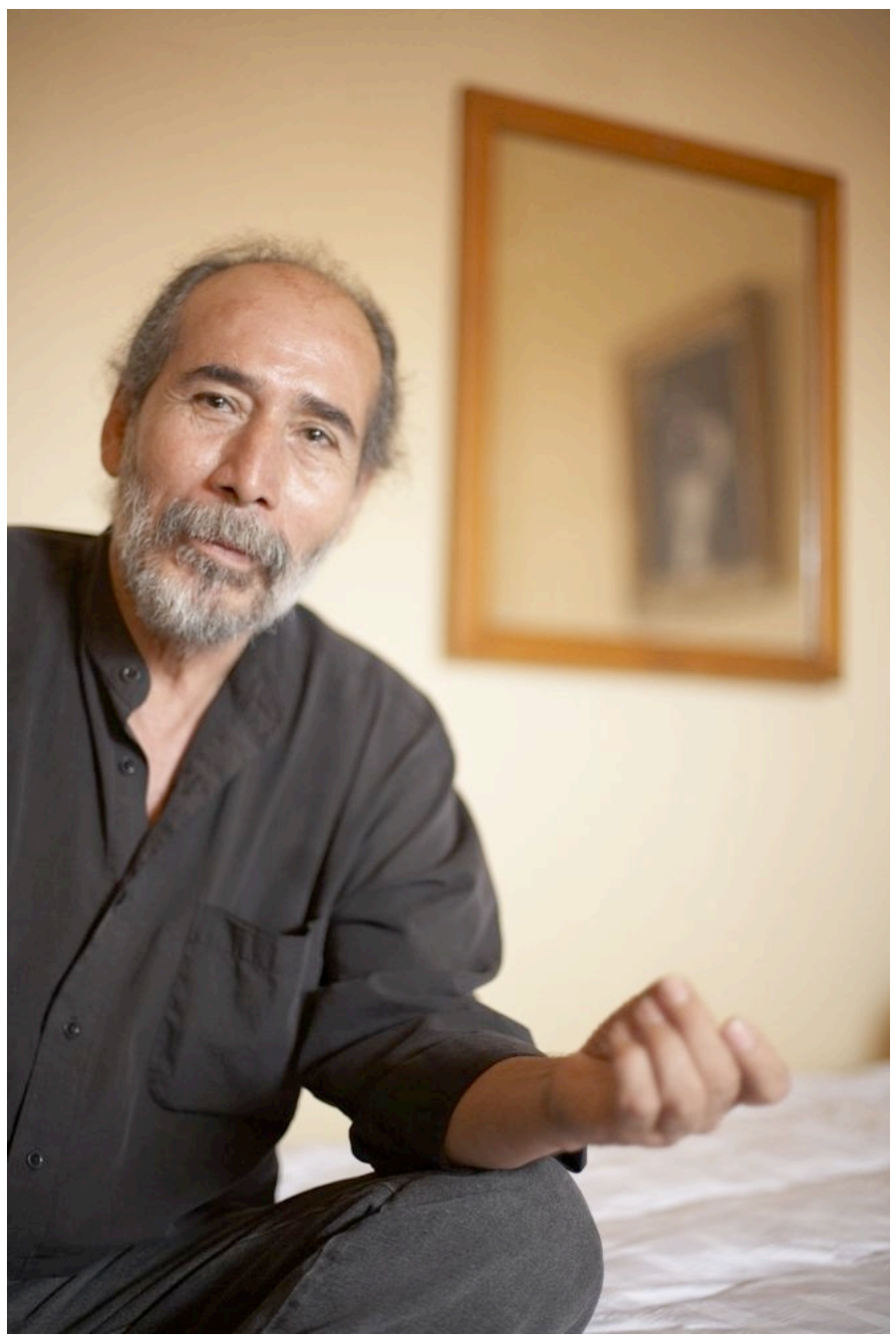

Image 7. Portrait of Mario Licón Cabrera, photographed by S. Rozario, 2009. 
'Hermosillo City Blues':

Those nights in Hermosillo; rather than walk

All the way down to my sister's place,

I would sleep under Yucateco trees

On steel park benches, or just over the mosaicos

Of plazas kioskos,

Like a real loafer.

This was nothing; I bypassed the long hike

In a high risk area.

Public transport stopped at ridiculous hours.

There I slept in the city's core

Amid the night-birds' song and cars skidding past

And some trios rehearsing for a serenata nearby. Memories

Arrived, memories from a distant childhood

And so on to memories of a non so distant Sydney.

I saw myself selling catholic newspapers at a cathedral.

So many big long marchas against university rectores.

I saw myself reaching the Palm Beach lighthouse.

Unpacking a ten-ton truck packed with clay

At Newtown. Dancing over the ferry

On the way back from Mackerel Beach.

I saw myself climbing El Tepozteco, the holy mountain.

Walking through pitch-black nights

Among rabiosos perros and their barking.

Missing Hermosillo, Sydney, Tepoztlán

And all at once.

Missing the nearby the far away

And the far close.

Mario Licón Cabrera was born in Chihuahua. He worked as a professional photographer and writer, and toured with a famous Mexican performing troupe as a puppeteer before arriving in Australia in 1992 and settling in Sydney. Since then he has continued his literary work. I asked Mario: What does it mean to be a poet? He answered: 'It is as if I 
asked you what does it mean to be alive? One has to breathe, it is who I am as you are who you are and to be alive you must breathe.' His poem, 'Hermosillo City Blues,' shows the complexities at play when memories take us to the many geographical locations along the trajectory of one's life. The transient artist's chronology is never lineal. There is no beginning-middle-end, accompanied by the weight of ancestral physical signifiers and referential points that surrounds our present moment in our present physical space. All the elements drawn by memories sustain us emotionally and psychologically, reassuring our sense of place and identity. In Mario's case, the role of memory summons the past to the present and the complexity of his daily interactions is shown in two languages, English and Spanish.

His poem begins with a recollection, 'Those nights at Hermosillo,' and the reader is prepared to enter a memory that will be expressed in both languages: 'Among rabiosos perros and their barking.' And as the poem and the night evolve we are taken through a nostalgic trip between Mexico and Sydney, a journey that will end in contradictions: 'Missing Hermosillo, Sydney and Tepoztlan all at once. Missing the nearby and the far away and the far close.'

Memory reinforced our sense of place and who we are, in Mario's case his life as a poet, writer and translator. There is a constant tension between who we are, what our work represents, and how that work is valued or taken into account. Who determines how relevant this work is, challenging the artists' identity and how they choose to express and produce their work? All artistic expressions confront some level of resistance, opposition or categorisation. For the writer language becomes another mode of complexity. In most cases Australian Latin American writers are published in their countries of origin, and in Sydney by Cervantes Publishing, a well-known publishing company that, since its founding in 1981, has supported bilingual publications in Australia from Spanish-speaking journalist and writers.

The artist's capacity is to see what is not evident. When we entered this new culture we had to learn its ways, manners and whims. Carlos saw this culture almost as an empty canvas and learnt it through his drawing pad and pencil. Mario sees his physical detachment form his place of birth and his bilingual capacity as enriching him as a writer. 


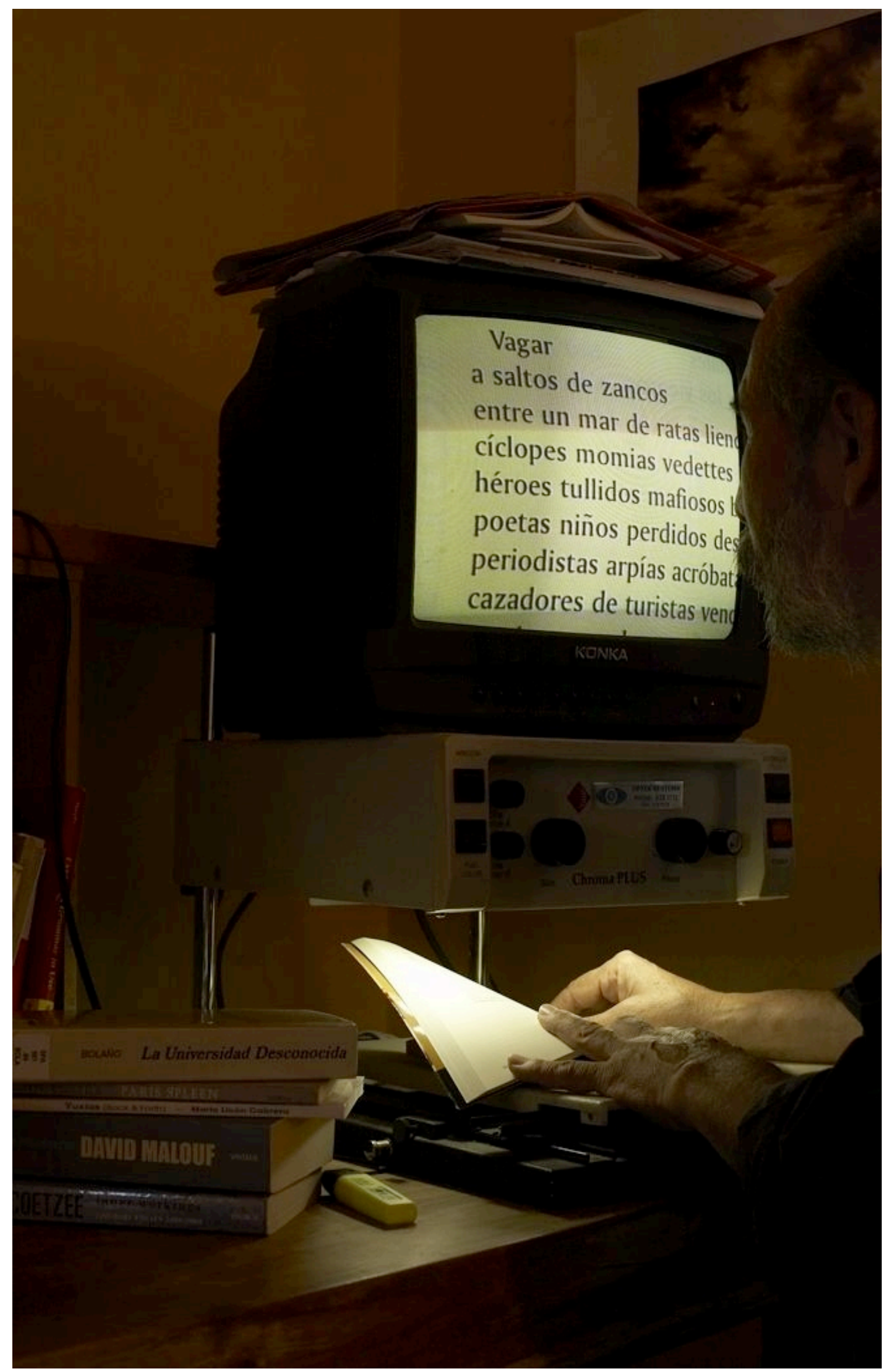

Image 8. Mario y la máquina de leer, photographed by S. Rozario, 2009. 


\section{Walter Rojas: En el ojo de la cámara-Through the eye of a camera}

Another example of transformation and creativity is the way in which Walter Rojas, a professional oboe player, once in Sydney learned new skills by taking on the camera to document his community's cultural and political activities.

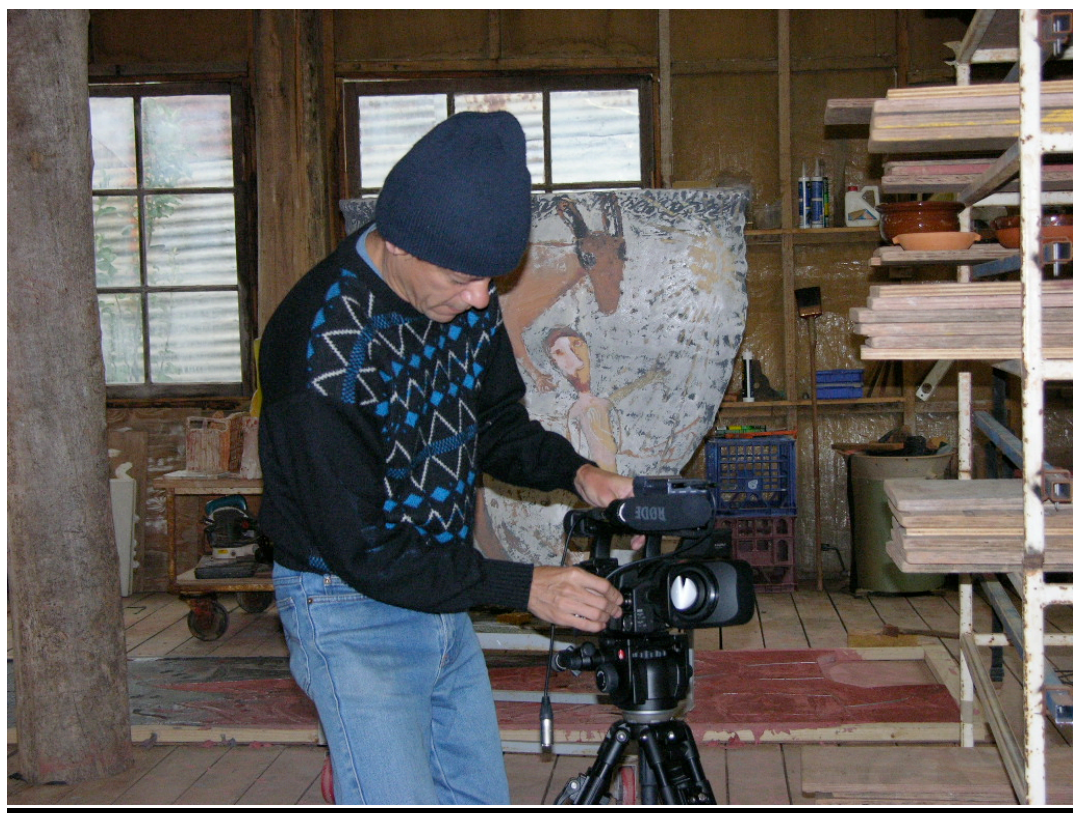

Image 9. Walter Rojas en La Paloma, Lino Alvares's studio, Hill End, photographed by L. Correa, 2009.

Walter was a graduate in music from the Centro Nacional de Artes de El Salvador, and when the civil war pushed him into exile, first to Mexico, he studied at La Escuela Nacional de Música de la Universidad Nacional Autónoma de Mexico (UNAM). Walter arrived in Sydney with his son in 1989. Once here he entered the Conservatorium of Music to finish his Bachelor of Music. I first met him at the studios of Radical TV in Leichhardt, where a group of Latinos had got together to work for 'Romperemos TV,' a series of programs for the Spanish speaking community to be broadcast through Channel 31 community TV.

I had been invited to introduce the Argentinean guitarist Luis Grimaldy; the TV program consisted of interviewing him about his career playing classical and Argentinean folklore music, while Carlos Barrios spontaneously painted to the music. In recent conversations I asked Walter about these early beginnings:

Se inicio en 1994 un proyecto que se llamaba Nueva Imagen en Bankstown Community Housing Association y allí había un fotógrafo Salvadoreño reconocido que había trabajado en los periódicos en el Salvador y le propusieron hacer un programa acerca de la cultura Salvadoreña y no conocía a 
otro artista y yo era el único artista en Sydney proveniente del Salvador que había estudiado música y arte el único artista que había era yo- Los demás eran músicos pero no eran artistas entonces éste compadre, Luis Aguilar me invitó a participar del proyecto fotografía y música esa fue la idea central de exponer sobre la cultura Salvadoreña. (Walter Rojas, Bronte, July 2009)

In 1994 a project titled New Image begun at Bankstown Community Housing Association and there was a renowned Salvadorian photographer who had worked in the Salvadorian media and they proposed to him to run a program about the Salvadorian culture. And he did not know any other artist and I was the only artist in Sydney coming from El Salvador who had studied music and art, all the others were musicians but not artists. Then this comrade, Luis Aguilar, invited me to take part in a project involving photography and music and that was the central idea how to display Salvadorian culture.

By 2009 Walter Rojas had collected large amounts of film footage of the Latin American community: political rallies, poetry readings, music, dance, theatre performances and festivals. He negotiated a space of visible existence in which Latin Americans were no longer categorised as 'hot - medium - mild,' but rather in relation to one's professional achievements. After many years of crosscultural collaborations, and projects ranging from mainstream film productions to community events, Walter today is a freelance filmmaker and teacher who, by documenting Australia's Latin American artistic contributions, provides a different perspective about Latin Americans in Australia. The cultural memories of the Latin American community translates into their artwork and have influenced how mainstream Australians perceive us as a community and as artists. Over the years I have seen numerous innovative approaches by exiled artists to their art practices and to their making sense of being unrooted.

Where is the value in rescuing some of these stories? Reflecting on this, and remembering my own experience and encounters with such a diverse, transient community, I have looked at the role of memory in artistic practice done outside one's culture of origin. And in an exercise of self-reflection, I have incorporated my own memories as a young migrant in the early1980s, as well as testimonial excerpts by artists who migrated to Australia between the late 1970s and the late 1990s. To recuperate some of these stories in the form of testimonials allows me to translate a desire to show and express who we are and how we work into a language that the cultural mainstream can understand.

In this way I want to challenge the notion of a fixed ethnic object, while exposing to full visibility Latin American subjects in constant motion, action and change, with memory sustaining our identity. The testimonials I gathered have shown me that artists acknowledge that the memory of place is pivotal in their artwork's conceptualisation 
and production in a new cultural context. Arias claims that testimonials allow us to express our subjectivities in a way that is true to our own modes of expression, since it uses our choice of aesthetics and language: 'Testimonios are often a first attempt to frame a rhetoric of being and to name agency for a particular subaltern group .... Their argument is framed in an ethical insistence on the right of subalterns to be themselves and thus implicitly defends cultural plurality or hybridity. Ethnicity is a language- and power-driven self-awareness' (2001: 80).

At another level I recognise that Australians have developed an appreciation of different artistic practices and aesthetics. They have come to terms with diverse cultural interventions not directly related to this country's indigenous history and legacy of colonisation. These cultural interventions, which I call permeations, do not perform ethnicity or simply represent difference or otherness; rather their impact rests on occupying a space of understanding and sustained integrity of practice, which contradict preconceived government agendas and definitions of ethnicity. Bhabha asserts:

The borderline work of culture demands an encounter with 'newness' that is not part of the continuum of past and present. It creates a sense of the new as an insurgent act of cultural translation. Such art does not merely recall the past as social cause or aesthetic precedent; it renews the past, refiguring it as a contingent 'in-between' space, that innovates and interrupts the performance of the present. The 'past-present' becomes part of the necessity, not the nostalgia, of living. (2004: 10)

The artists' works are encrypted with their makers' identities and, therefore, their memories. But these articulations are embedded within a space of present temporality, claiming and asserting a new sense of place and belonging while 'renewing the past.' In a sense a story begins in that precise moment with someone picking up the line another left, with decisions to tell and continue the writing.

\section{Jorge y Marcela: En el cotidiano arte del hacer-In the daily making of art}

Jorge Bagnini is the Multicultural Arts Officer for Canberra, actor, theatre director and playwright. Since his arrival to Australia Jorge has created and managed many cultural projects at a mainstream level as well as with the Canberra Spanish speaking community. His productions are in English and Spanish, or with subtitles when necessary. In February 2008 María de Buenos Aires was presented at the Canberra Playhouse as part of the Canberra Multicultural Festival. This operetta is the work of 


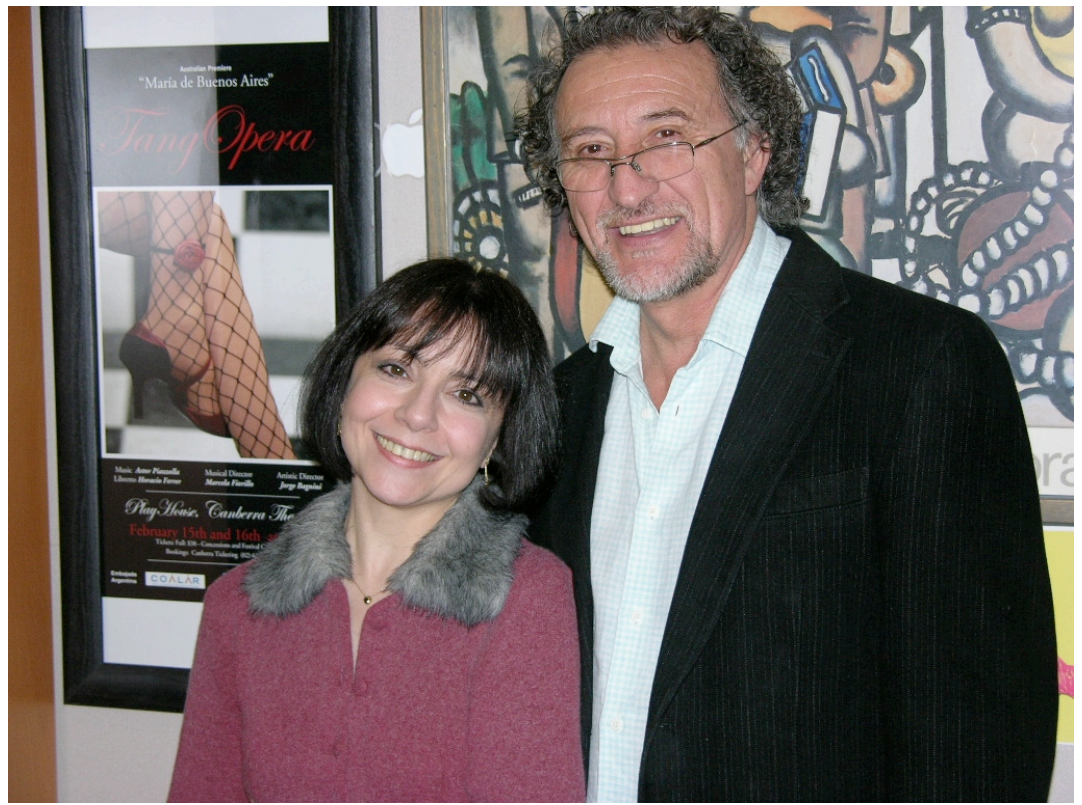

Image 10. Jorge Bagnini y Marcella Fiorillo, photographed by L. Correa, 2009.

renowned Argentinean composer Astor Piazzolla, with poetry by Horacio Ferrer. ${ }^{4}$

Producing this work in Australia was one of Jorge and his wife Marcela's projects for a number of years. Their second attempt to introduce Australian audiences to one of the greatest pieces of contemporary Argentine music did not entail mere reproduction of some learnt act or technique. Nor did it mean replaying Piazzolla's love story to his most beloved city, or bemusing audiences with exotic representations. Rather, as Jorge Bagnini states:

Seguimos haciendo lo que sabíamos mejor hacer. El motivo detrás de montar María de Buenos Aires o seguir haciendo teatro en Español va más alla de que un recuerdo se realice y se muestre sino es que todos los días nos cuestionan o nos niegan la identidad. (Jorge Bagnini, Canberra, May 2009)

We continue doing what we knew best. The motivation behind producing María de Buenos Aires or continuing to make theatre in Spanish goes beyond the realisation of a memory that can be shown. It has to do with the fact that everyday our identity is negated or gets questioned.

When it was finally staged, Maria de Buenos Aires was considered one of the highlights of the Canberra Multicultural Arts Festival. Attending one of the performances, it was impossible not to notice the complexity of what had been achieved. Copyright issues prevented the material from being performed in any other language but Spanish, so the poetry that narrates the story was interpreted for the English-speaking members of the audience, and projected onto a screen.

Ferrer's poems were originally written in lunfardo, the slang of Buenos Aires that is

\footnotetext{
${ }^{4}$ María de Buenos Aires premiered at Sala Planeta, Buenos Aires, in 1968.
} 
almost impossible to translate. Nevertheless, despite limited arts funding, Jorge and Marcela invited a personal friend baritone, Eduardo Cogorno, to perform the main role. Eduardo flew to Australia at his own cost. The performance went ahead after Marcela's sleepless nights arranging the material within limited resources. On stage was also the Australian mezzo-soprano Bronwyn Sullivan, the Sydney-based Argentinean actor Alejandro Machurón, Marcela Fiorillo on piano, members of the Australian Chamber orchestra on strings, and a chorus made up of community members who gave their time to the production free of charge. ${ }^{5}$

One audience member mentioned that when he heard on the radio that Piazzola's work was going to be performed live, he decided to travel from his country property on the outskirts of Canberra into the city, since he had been a fan of the work for many years. The audience was a mix of ages and cultures. It was impossible for me to witness such a transcultural experience without thinking about the work's production. I recognised members of the performing troupe, and knew in detail, through my past experiences producing and directing performances in cross-cultural contexts, how enriching and complex these experiences can be. Yet as a member of the audience and community, my feelings ranged from an enormous sense of pride to frustration. I was aware of how the quality of the work could have been improved with better conditions.

These conditions are not always the result of limited funding. If the telling of a story is perhaps the telling of many stories, then Jorge and Marcela decided to unfold one story by means of theatrical and musical language.

\section{Conclusion}

Valuable cultural memories are embedded in the cultural work produced in the Australian Latin American community. Performances, art works, and cultural spectacles and spaces, are symbols of identity directly connected to the perception and appreciation by mainstream Australians of Latinos and their cultural productions. Exiled Latin American artists transform themselves through innovative art practices that allow them, and their communities, to deal and negotiate with a profound sense of being unrooted. The loose mapping in this paper of selected Australian Latin American cultural achievements and stories indicates the extent to which art productions are also

\footnotetext{
${ }^{5}$ One unfortunate absence was the bandoneón-a type of concertina, and a pivotal instrument in a tango orchestra-for economic reasons rather than due to a lack of skilled performers.
} 
testimonials of our community's cultural memory.

Dónde comienza la historia? La que quiero recuperar y contar sólo por un capricho o una necesidad de sentir algún hilo conductor hacia lo posible en medio de tanto desfasaje cultural. En los '60s cuando dos misioneros paraguayos visitaron Australia y en casa de Pedro y Susan por primera vez en este país se palpo y se escuchó el sonido de un arpa paraguaya? O cuando a Diana la presentaron en el Caballo Blanco de Blacktown como el último acto de la canción española mientras ella se preparaba para entonar zambas de la pampa argentina? Tal vez la historia comience en todas partes, en el café del español cascarrabias y en Georgina Street donde nació La Peña y con cada "unsound less ideological nä̈ve mistake or assumption" como un quilt Welsh o como un tapiz peruano. Pedazos de historias, matices, sonidos, olores y sabores, que se tejen y destejen con cada muerte en el exilio, con cada partida y en cada llegada. Es aqui entonces y desde este pedazo de herencia cultural en un intento de rescatar recuerdos y vivencias que alguna historia comience. Does the story begin in the $1960 \mathrm{~s}$ when two Paraguayan missionaries arrived at Pedro and Susan's house and, for the first time in Sydney, the sound of a Paraguayan harp was heard? Or perhaps with Diana's story when she decided to travel from Argentina to Australia to join her father during the early 1970s? She asked a friend what was Australia's largest city and where she could find work. Landing in Sydney Diana found her way to the Blacktown pub, El Caballo Blanco, where a North American woman, the pub's manager at the time, met her. Half in sign language with guitar in hand, half in broken English, Diana embarked on her first job in Australia, and on the same night was introduced centre stage, dressed in full Spanish costume, as the latest act from Spain. Picking up her guitar she begun to sing zambas and chacareras, folkloric rhythms from Argentina, to bemused audiences who had never heard or seen anything like it. Perhaps the story begins everywhere: with the sound of a harp playing somewhere in Glebe, with Diana singing in Blacktown, with the ill-tempered Spaniard café owner on Liverpool Street, with the borth of La Peña on Georgina Street. Does our story begin with each unsounded naïve mistake or the assumption underwritng the inquisitive and challenging gaze of others? Like a Welsh quilt or Peruvian tapestry, pieces of histories, shades of color, smells, sounds and tastes, all inter-weaved with each exiled death, with each arrival and departure.

It is here, then, in an attempt to recuperate what was lived, that a story begins. As we 
move from one country to another we carry with us a cultural identity, and an idea of place, that enable our creative practices to continue. Memory, dynamic and in interactive dialogue with others, sustains us in this journey. Artists from distinct cultures to the dominant one they encounter in the host country must always validate and justify their locations and choices of art practice. Tensions arise through a constant questioning of one's origins, and skills, which may diminish the relevance of our art work in the context of mainstream Australian culture. Nevertheless, the artists introduced here continue to engage at many levels with both mainstream professional practices and community or grassroots contexts. They are in motion and interaction, transcending culturally specific boundaries, continuing to negotiate our sojourn in this country.

\section{Reference List}

Arias, A. 2001, 'Authoring Ethnicized Subjects: Rigoberta Menchú and the Performative Production of the Subaltern Self,' PMLA, vol. 116, no. 1, 75-88.

Barthes, R. 1979, A Lover's Discourse: Fragments. Jonathan Cape, London.

Bennett, J. 2008, Emphatic Vision: Affect, Trauma and Contemporary Art. Stanford University Press, Standford.

Bhabha, H. 1994, The Location of Culture. Routledge, London.

Cabrera, L. M. 2007, Yuxtas (Back and Forth). Cervantes Publishing, Australia.

Coronado, G. 2003, 'Crossing Borders and Transforming Identities.' Humanities Research, vol. 10, no. 1, $41-52$.

Coronado, G. 2009, unpublished manuscript: Olor, lugar y memoria. México en las representaciones cinematográficas y el sostenimiento emocional del emigrante. University of Western Sydney.

Engels, S. 1999, Context is Everything. The Nature of Memory. W.H. Freeman \& Company, New York.

Grishin, S., \& Shead, G. 2007, Garry Shead: The Apotheosis of Ern Malley. Australian Galleries, Sydney.

Morrison, T. 1990, 'Wild Tongues: Affirming Identities,' in (eds) Ferguson, R., Gever, M., Minh-ha, T. \& West, C., Out There: Marginalization and Contemporary Cultures. MIT Press, New York, 299305.

Willis, P. 2000, The Ethnographic Imagination. Polity Press/Blackwell, Cambridge. 